\title{
Information Anxieties and Information Distrust: The effects of Overload Information about COVID - 19
}

\author{
Roro Isyawati Permata Ganggi* \\ Library Sciences, Culture Department, Faculty of Humanities, Diponegoro University, Indonesia
}

\begin{abstract}
Covid-19 is the world's main focus, so the mass media is competing to provide details information. The amount of information related to Covid-19 in the communities raises information overload. The purpose of the study is to know the effects of overload information about Covid-19 on the information of anxiety and distrust of information about the people of Semarang. This research uses quantitative methods. The samples in this study were one hundred and fifty seven respondents which is acquired using random sampling. The Data in this research was obtained through online questionnaires. Data is presented descriptively because in this study using an open-ended questionnaire. The results showed that overload information about Covid-19 triggers the occurrence of anxiety information. The anxiety of the information itself has an impact on the rise of laziness to searching information and fatigue of information, where both lead to information distrust.
\end{abstract}

\section{Introduction}

Corona Virus Disease 2019 are commonly known as Covid-19. World Health Organization (WHO) states that Covid-19 as a pandemic. WHO reported on 26 May 2020 there have been 5.307.298 peoples around the world that infected and including 342.070 deaths because Covid-19 [1]. A vaccine for this virus is still not found. As a pandemic Covid-19 has been the main focus of the world. Being a main focus of the world then many mass media are preaching about Covid-19. Based on early observations it was found that not only media which disseminating information, but also communities took part in disseminating information about Covid-19.

The use of smartphone and internet is a cause of overload information that occurs today [2]. Information overload occurs when information is greater than the person's ability to process that information [3]. The amount of information related to COVID-19 circulating in the communities is not entirely true. Sometimes the information contains hoaxes. The Indonesian Ministry of Communications and Informatics recorded until 16 April 2020 at least 1,125 hoaxes about Covid - 19 [4]. Information overload about Covid-19 is feared can cause confusion in society even raises anxiety and distrust of information. The anxiety information that happens will make antipathy information and society have no attempt to

* Corresponding author: r.isya.ganggi@live.undip.ac.id 
find credible information about Covid-19. The absence of attempts to find credible information makes the societies easier to believe in the hoaxes.

This research is focused on the peoples of Semarang because Semarang is one of the red zone of Covid-19. Based on the problems described earlier, it needs to be researched deeply whether with much information related to Covid-19 in societies will make the community more relief or not. To see the matter then the research is focused on how the impact of information overload related Covid-19 to the anxiety and distrust of information on Semarang society.

\section{Methodology Research}

This research used quantitative research methods. Quantitative research was chosen because quantitative research was considered the right type of research to conduct generalization research [5]. Data retrieval in this study will be conducted with survey. The survey method is used so to capture many respondents. The population in this research is Semarang City societies. The research sampling is done by cross-sectional method. The cross-sectional method is the proper sampling method for survey research [6]. Sampling calculation with error tolerance 0.05 , obtained one hundred and fifty seven respondents. Respondents are selected with random sampling technique.

Survey in this study is conducted by distributing an online questionnaire through Google form the questionnaire consists of 38 questions. The questionnaire used in this research was an open-ended questionnaire. The open-ended questionnaire was used to capturing the spontaneous answer from respondents so can avoid any bias arising from the answer options provided [7]. Data that accumulated later was analysed by using thematic text analysis. Thematic text analysis is a method to find the cause of a theme and then classify it according to the theme found [8]. The presentation of the data in this study is descriptive.

\section{Results and Discussions}

Respondents in this study ranged between the ages of 16-52 years, consisting of 45 men and 112 women. Almost all respondents are people who can use the internet primarily in communicating and information searching. They use instant messenger (IM) and social media. The most frequently used Instant Messenger (IM) is WhatsApp (88\%) and the most frequently used social media is Instagram (69\%). Based on data analysis then there are two data groups, namely: (1) Information behaviour about Covid-19 (2) Information anxiety and information distrust about Covid-19.

\subsection{Information Behavior about Covid-19}

Covid-19 has attracted a lot of people's attention, that's why many media preach about Covid-19. It is seen from as many as $59 \%$ of respondents still do a search of information related to Covid-19 with their own business, while $41 \%$ of respondents get information related to Covid-19 only from instant messenger (IM) or news that appears on their social media timelines. Information related to Covid-19 is very easy to obtain, even when opening social media that information automatically appears or even the information comes through a broadcast message in the instant messenger. The use of social networking sites (social media and instant messenger) is slightly more influential in the creation of information overload [9]. Although the information related to Covid-19 is widely circulated but most of the respondents are aware of where is location of credible information related to Covid-19. 
A total of $25 \%$ of respondents did a search for information about Covid-19 through the official website of government. $18 \%$ of respondents searched for information about Covid19 on social media, and $17 \%$ of respondents searched through online news. While the rest search through Google (14\%), electronic media such as television and radio (9\%), journals $(9 \%)$, and broadcast information $(8 \%)$.

Video (42\%) is a type of presentation of information that is easiest to understand by the community, while $40 \%$ of respondents are easier to understand the written information, while the remaining $18 \%$ better understand if the information presented in the form of infographics. Information about Covid-19 is very easy to obtain by the community, at least $75 \%$ of the community states that they are easy to search for Covid-19 information. Although the information about Covid-19 is easy to obtain but $61 \%$ of respondents are still have difficulties to decide the truth of the information they get. Respondents had difficulty in deciding about the truth of information about Covid-19 for fear that the information they get was hoax. This shows though the information about Covid-19 is very much but the public had difficulties to absorb the information, so the information becomes ineffective. Information becomes ineffective because overload information sometimes containing hoaxes [10].

Overload information about Covid-19 was felt by the respondent. $83 \%$ of respondents felt that information about Covid-19 was too much. According to respondent, Covid-19 information is very much and very easy to obtain, both print and electronic information. Easily, when respondents opened their social media Covid-19 information automatically appears on their timeline. Although the information about Covid-19 is easy to obtain, the community still worries and confused if the news they get is hoax news. $53 \%$ of respondents stated that they were being confuse because of too much information. To be able to avoid hoax, society considering the source or location of information (58\%), the person in charge of information (17\%) and images, sounds, videos included in the information $(17 \%)$ and the rest see from the information title.

35 respondents tend to ignore, if the information obtained is hoax. This waiver demonstrates the passive usage behavior information. Abandonment of information indicates a lack of time, experience, energy and personal interest in the information [11]. Only $23 \%$ of respondents took the initiative to re-check the information they get. This shows that few respondents are the active usage behaviour information so they need to find the truth of the information they are getting.

\subsection{Information Anxiety and Information Distrust about Covid-19}

A lot of information related to Covid-19 makes respondents feel worried, afraid and uncomfortable after searching for information, there are at least $63 \%$ of respondents who feel it. This is in line with previous research where the effects of information overload are psychological stress, exhaustion, anxiety, negative affect or decreases in work performance [12]. The kind of information that often triggers worry and anxiety of respondents is fake news and information with a hyperbola title. This condition can be explained with research of Yeung and Fernandes [13], that when someone's attention to irrelevant information increases then the speed in processing the information becomes slow thereby causing anxiety. There is a lot of informations with the bombastic and hyperbola title, so peoples are interested in reading that information, or known as clickbait. Clickbait is information in digital form that aims to attract the attention and curiosity of someone so that people will click on that information [14].

$25 \%$ of respondents stated that the overload of information precisely made them calmer. Respondents felt calm because of the sheer amount of information they could compare information from various sources. Respondents who feel calmer about the overload 
information are respondents who have a good level of literacy where they usually compare information before making a decision. Information literacy has the same concept as critical thinking and this concept making easier to make decisions [15]. While the other $20 \%$ are indifferent to the existing information. Respondents felt anxious, worried and uncomfortable in finding information about Covid-19 but as much as $52 \%$ of respondents still continued to search. Respondents continued the search as they wanted to know the truth of the information and reduce anxiety arising from search. While the rest as much as $48 \%$ stopped to do searching because fear if they done more seeking information, they will feel more anxiety. Although many respondent are worried and uncomfortable with information search results but $83 \%$ of respondents did not regret having done a search.

New problems arising from information anxiety about Covid-19 information are the laziness to seek information and fatigue to seek information. Based on the results of the questionnaire data then it is known that $70 \%$ of respondents have ever felt lazy to do information seeking. This laziness is triggered because the respondent feels that searching a credible information needs to go through a series of complicated processes. Laziness will make someone did not "make an effort " so that they just surrender to what is owned [16]. Laziness to search for information will make someone more easily believe hoax news. Fatigue perceived by respondents is cognitive fatigue. Cognitive fatigue makes users information more likely to be away from information when they feel overwhelmed by too much information and time it takes[17]. Both of information fatigue and lazy of searching information creates information distrust. $72 \%$ of respondents ever feeling distrust the searching results of Covid-19 information they did. Overall the mining of data that is presented in the form of diagram as below:

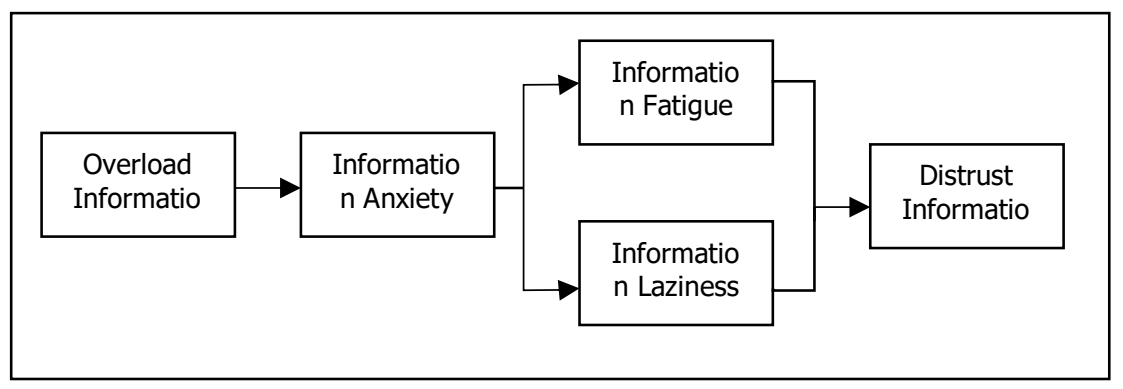

Fig. 1. Diagram of data result

\section{Conclusions}

The impact of the information overload related Covid-19 is the occurrence of information anxiety. Information anxiety occurred because the respondent realized, although the information related to Covid-19 is very much but it actually makes the respondents difficult to find information that can be trusted. The Hyperbola news title also contributes to the information anxiety related to Covid-19 that happened. There are two effects that arise due to anxiety information, namely: laziness information and information fatigue. Laziness of information occurs because the respondent feels that information retrieval is something complicated. While information fatigue makes respondents avoid credible information search activities. Both laziness of information or fatigue of information can trigger the distrust condition of information. Information distrust makes people more easily believe in hoaxes, so there needs to be further education for the community on how to find credible information that is effective and efficient way. 


\section{References}

1. WHO, Coronavirus Disease (COVID-19) Pandemic. Avaible: https://www.who.int/emergencies/diseases/novel-coronavirus 2019?gclid=Cj0KCQjwiYL3BRDVARIsAF9E4GcdMuJXi8z6b9ruFZ7DxXJZTYG 6IzjMCdgUaG0ddXP1U87IIRaxEaAq8xEALw wcB

2. G. R. Peter, Information overload in the information age: a review of the literature from business administration, business psychology, and related disciplines with a bibliometric approach and framework development, Business Research 12 (2), 479522, (2019)

3. R.S. Wurman, Information Anxiety 2, Indianapolis: Que (2001)

4. Detik. 16 Kamis 2020. Pemerintah: 1.125 Hoax Soal Corona Terdeteksi, Jangan Tambah Beban Psikologis. Avaible: https://news.detik.com/berita/d4979655/pemerintah-1125-hoax-soal-corona-terdeteksi-jangan-tambah-bebanpsikologis

5. P. Corbetta, Social Research: Theory, Methods, and Techniques, London: Sage Publications (2003)

6. S. Lemes, W.H.Jr. David, Besar Sampel dalam Penelitian Kesehatan (terjemahan). Yogyakarta: Gadjahmada University Press (1997)

7. U. Reja, K. L. Manfreda, V. Hlebec, V. Vehovar, Open-ended vs. Clodes-ended Questions in Web Questionnairies, Developments in Applied Statistics 19, 159 -177, (2003)

8. R. Popping, Analyzing Open-ended Questions by Means of Text Analysis Procedures, Bulletin de Méthodologie Sociologique 128, 23 - 39, (2015)

9. A. R. Lee, S. Son, K. K. Kim, Information and Communication Technology Overload and Social Networking Service Fatigue: a Stress Perspective, Computer in Human Behavior 5, 51 - 61, (2016)

10. S. Talwar, A. Dhir, P. Kaur, Why Do People Share Fake News? Associations between the Dark Side of Social Media Use and Fake News Sharing Behavior, Journal of Retailing and Consumer Services 51, 72 - 82, (2019)

11. Y. Guo, Z. Lu, H. Kuang, C. Wang, Information Avoidance Behavior on Social Network Sites: Information Irrelevance, Overload, and The Moderating Role of Time Pressure, International Journal of Information Management 52, 1- 12, (2020)

12. J. Matthes, K. Karsay, D. Schmuck, A. S, "Too Much to Handle”: Impact of Mobile Social Networking Sites on Information Overload, Depressive Symptoms, and WellBeing, Computers in Human Behavior 105, 1 - 11 (2020)

13. R. C. Yeung, M. A. Fernandes, Social Anxiety Enhances Recognition of TaskIrrelevant Threat Words, Acta Psychologica 194, 68 - 76, (2019)

14. S. Kaur, P. Kumar, P. Kumaraguru, Detecting Clickbaits Using Two-Phase Hybrid CNN-LSTM Biterm Model, Expert Systems with Applications 151, (2020)

15. M. Goodsett, Best Practices for Teaching and Assesing Critical Thinking in Information Literacy Online Learning Object, The Journal of Academic Librarianship, (2020)

16. T. Madsen, The Conception of Laziness and the Characterisation of Others as Lazy, Human Arenas 1, 288 - 304, (2018)

17. M. Y. Hwang, J. C. Hong, K. H. Tai, J. T. Chen, T. Gouldthorp, The Relationship between The Online Social Anxiey, Perceived Information Overload and Fatigue, and 
Job Engagement of Civil Servant LINE users, Government Information Quarterly 37 (1), (2020) 